原著

\title{
歯冠の透明感覚尺度の構成
}

\author{
森山旭 \\ 東京医科歯科大学歯学部高齢者歯科学講座（指導：長尾正憲教授）
}

(1994 年 9 月 30 日 受付)

\section{Psychophysical Scaling of Translucent Sensory Measurement of Tooth Crowns}

\author{
Noboru Moriyama \\ Department of Geriatric Dentistry, Faculty of Dentistry, Tokyo Medical and Dental University \\ (Director : Prof. Masanori Nagao)
}

The purpose of this study is to investigate the translucent sensory measurement as a basic study for developing the translucent sensory scale (Haze Guide) of tooth crowns. Seven subjects with normal visual sensation were examined to search for the translucent sensory interval of uncertainty using methods of limits, and 3 panels were selected from this result and prepared for further experiments. Fact-findings of the translucent senses were performed on these 3 panels using the magnitude estimation method and the absolute judgement method. With these methods we were able to construct the translucent sensory measurement and to establish the ranges of Haze scores and magnitude of each step and a permitted limit of each Haze tab, which should be possessed with the tooth crown translucent sensory scale.

The results were as follows:

1. The translucent senses were well adapted to the Stevens power law of modality characteristic exponent. The exponent was 1.74 .

2. Standard light translucent sensory guide for tooth crowns were in the range between 25 . $2 \%$ and $91.9 \%$ at Haze values. Eighteen steps were arranged within this range, and when the Haze difference was taken larger at lower Haze values and the difference was taken smaller accordingly at higher values, the visual sensation came to achieve an equally appearing interval of translucency.

\section{I 。緒}

歯冠色の研究が進む一方で，人工歯のリアリ ティーのための要件については, 光透過性と光沢 の 2 要素が不可欠という指摘はなされても1 7), 研 究方法が確立されていないために遅々として進ん でいない。多くの歯冠色の研究報告のなかで, 加藤 ${ }^{8)}$ みは切端部について独特の見解を明らか
にした。すなわち, 上顎前歯の歯冠切端側 $1 / 3$ に ついては, 色の 3 属性の計測を行ったが, 外観に 及ぼす歯の個性は色違いよりも, 透明性の違いの ほうが大きいとした。その後, 指宿 ${ }^{9}$ が単独で歯冠 用の透明感のガイドを開発する基礎的な実験を 行ったが，実用の域には達しなかった。

透明感という視覚情報を感覚を起こさせる原刺 激の特性として捉えるか, 刺激によって起こされ 
た結果としての感覚の側で評価するかの違いは実 験の大きな岐路であるが，臨床的には感覚の側で 捉えるほうがわかりやすく，しかも研究成果を臨 床に直接反映させやすいと考えた。そこで，視感 比色法における標準色票に相当するガイド（歯冠 用標準光透過票，ヘーズガイド）を開発する基礎 的な研究として，透明感の感覚尺度について検討 した。

\section{II. 方法および材料}

本実験は大別して 2 つからる。第 1 実験は透 明感覚尺度を具体化するために，7人の被験者に ついてその透明感覚を実験心理学の極限法 ${ }^{10} に よ$ り調查し, 刺激に対する主観的等価点と不確定範 囲を求め, 第 2 実験に必要な官能検査パネルを選 出した。第 2 実験は歯冠用標準光透過票 (ヘーズ ガイド）の理論值と許容へーズ差を明らかにする ことである。そのためには, 選出した官能検査パ ネルについて, やはり実験心理学の手法であるマ グニチュード推定法 ${ }^{11)}$ 用いてへーズ值と透明感 の大きさを，また絶対判断法 ${ }^{12)}$ 用いてへーズ值 と透明感を言葉で表現した場合のカテゴリーの整 合性について調査した。以上の実験をもとに，透 明感感覚尺度を構成し，歯冠用標準光透過票を作 成する際のへ一ズ值の範囲とステップ, 許容へー ズ差を求めた。

\section{1. 第 1 実験 ヘーズの弁別閾}

官能検査の手法の一つである, 極限法を用いた。 すなわち，テスト用カードは，図 1 に示すような 1 辺 $15 \mathrm{~cm}$ の正方形をした明度 7 の無彩色を背 景にして, 中央には $1 \times 1 \mathrm{~cm}$ の空がある。その空 の裏面に，刺激となるポリプロピレン・シートが 貼ってある。右の空を標準刺激として, 左の空は 系列刺激を順次提示する。初めは, 左右のへーズ 值（量価）の違いを一目で識別できるほど大きく してある。しかし，順次系列刺激のへーズ值を標 準刺激に近づけて行くと，あるところでその違い がわからなくなるところがあり，そこで打ち切る。 実験は，テスト法になれるために 1 度練習した

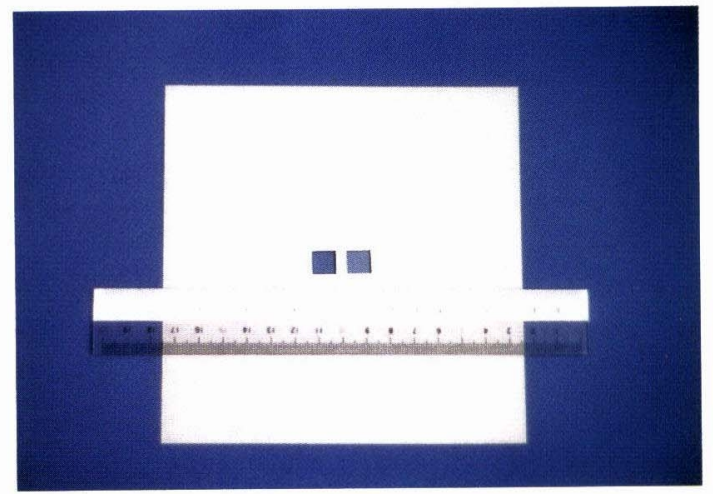

図 1 極限法によるへーズ差識別テスト用カードの 一例。右の悹は標準刺激, 左の空は比較刺激。微 少なへーズ違いのものから大差までの系列刺激 を用意した

後，同一被験者に対して上昇系列と下降系列の 2 回老 1 セットとして同一日に 2 セット行い，3 日 間で合計 6 セット行った。1 度目は系列刺激を標 準刺激よりへーズ值が高いほうから順に低めて行 くように変化させ， 2 度目は逆にへーズ值の低い

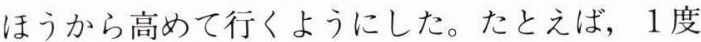
目の実験では次のように被験者に指示する。「左の ほうが右より明らかに不透明になっています。そ うですね」と確認させた後，「それでは，これから 左のほうの不透明度を順に変えて行きますから， 左右が等しくない時は等しくないと，わからない あるいは確かに等しいと感じる時は，わからない とか等しいといって下さい」。

半透明の物体としては, 薄手の $0.02 \mathrm{~mm}$ 厚の ポリプロピレンシートを十数枚と厚手の $0.5 \mathrm{~mm}$ 厚のものを数枚用意し，適宜重ね合わせてへーズ 值を変えるようにした。薄手のシートは 1 枚で ヘーズ值が $1.0 \%$ 前後，厚手のものは同じく 20.0〜 40.0\%である。これらのシートを重ね合わ せた時に，へ一ズ值は単純に加算されるのではな く，加算した価より低く複雑に変化するので，刺 激を変えるごとに測定器に掛けてへーズ值を確認 した。標準刺激のへーズ值は, 5.0\%から 10\%違い で $85.0 \%$ まで 9 段階用意した（表 1 ）。 
表 1 標準刺激に対する各被験者の不確定範囲

\begin{tabular}{|c|c|c|c|c|c|c|c|c|c|c|c|}
\hline & & & & & & 準刺激 & & & & & \\
\hline & & 目標値 & 85.0 & 75.0 & 65.0 & 55.0 & 45.0 & 35.0 & 25.0 & 15.0 & 5.0 \\
\hline & & 実測値 & 85.3 & 75.6 & 66.4 & 56.5 & 45.9 & 35.6 & 26.5 & 13.4 & 6.1 \\
\hline & & 上 & 86.1 & 75.6 & 67.0 & 57.4 & 46.9 & 37.2 & 28.5 & 18.4 & 14.6 \\
\hline & A & 下 & 85.0 & 74.4 & 65.5 & 55.5 & 44.9 & 33.5 & 24.0 & 8.8 & $3.1^{*}$ \\
\hline & (M. 50) & PSE & 85.6 & 75.0 & 66.3 & 56.5 & 45.9 & 35.4 & 26.3 & 13.6 & - \\
\hline & & RAN & 1.1 & 1.2 & 1.5 & 1.9 & 2.0 & 3.7 & 4.5 & 9.6 & - \\
\hline & & 上 & 85.8 & 76.6 & 67.0 & 57.4 & 48.1 & 37.2 & 28.5 & 18.4 & 24.3 \\
\hline & B & 下 & 84.7 & 75.3 & 65.3 & 55.1 & 43.5 & 33.5 & 23.7 & 6.3 & 3.5 \\
\hline & (F. 33) & PSE & 85.3 & 76.0 & 66.1 & 56.8 & 45.8 & 35.4 & 26.1 & 12.4 & 13.9 \\
\hline & & RAN & 1.1 & 1.3 & 1.7 & 2.3 & 4.6 & 3.7 & 4.8 & 12.1 & 20.8 \\
\hline & & 上 & 85.8 & 74.4 & 67.4 & 57.4 & 48.1 & 37.2 & 29.4 & 17.9 & 17.9 \\
\hline 被 & C & 下 & 84.3 & 72.6 & 65.3 & 55.1 & 43.5 & 33.7 & 22.5 & 6.3 & $3.1^{*}$ \\
\hline & (M. 30) & PSE & 85.0 & 73.5 & 66.4 & 56.8 & 45.8 & 35.5 & 26.0 & 12.1 & - \\
\hline 歌 & & RAN & 1.5 & 1.8 & 2.1 & 2.3 & 4.6 & 3.5 & 6.9 & 11.6 & - \\
\hline 者 & & 上 & 85.8 & 76.6 & 67.0 & 57.4 & 46.9 & 37.2 & 28.0 & 17.9 & 14.6 \\
\hline & $\mathrm{D}$ & 下 & 84.6 & 75.3 & 65.5 & 55.5 & 44.6 & 33.5 & 23.4 & 7.9 & $3.1^{*}$ \\
\hline & (M. 25) & PSE & 85.2 & 76.0 & 66.3 & 56.5 & 46.2 & 35.4 & 25.7 & 12.9 & - \\
\hline 男 & & RAN & 1.2 & 1.3 & 1.5 & 1.9 & 2.3 & 3.7 & 4.6 & 10.0 & - \\
\hline & & 上 & 87.2 & 76.6 & 67.4 & 57.7 & 48.1 & 37.2 & 29.4 & 18.4 & 25.1 \\
\hline & E & 下 & 85.0 & 75.0 & 65.3 & 55.5 & 43.5 & 33.5 & 22.5 & 6.3 & 3.5 \\
\hline 女 & (F. 25) & PSE & 86.1 & 75.8 & 66.4 & 56.6 & 45.8 & 35.4 & 26.0 & 12.3 & 14.3 \\
\hline & & RAN & 2.2 & 1.6 & 2.1 & 2.2 & 4.6 & 3.7 & 6.9 & 12.1 & 21.6 \\
\hline & & 上 & 85.8 & 76.0 & 67.0 & 57.4 & 46.9 & 36.8 & 28.5 & 16.4 & 17.9 \\
\hline 年 & $\mathrm{F}$ & 下 & 84.8 & 75.0 & 65.3 & 55.5 & 44.9 & 33.5 & 24.0 & 7.9 & $3.1^{*}$ \\
\hline & (F. 22) & PSE & 85.3 & 75.5 & 4.2 & 56.5 & 45.9 & 35.2 & 26.3 & 12.2 & - \\
\hline & & RAN & 1.0 & 1.0 & 1.7 & 1.9 & 2.0 & 3.3 & 4.5 & 8.5 & - \\
\hline & & 上 & 86.1 & 76.6 & 67.0 & 57.4 & 47.9 & 38.6 & 28.5 & 18.4 & 18.4 \\
\hline & G & 下 & 84.4 & 74.6 & 64.6 & 54.2 & 43.5 & 32.6 & 21.5 & 4.9 & $3.1^{*}$ \\
\hline & (M. 18) & PSE & 86.3 & 75.6 & 65.8 & 55.8 & 45.7 & 35.6 & 25.0 & 11.7 & - \\
\hline & & RAN & 1.7 & 2.0 & 2.4 & 3.2 & 4.4 & 6.0 & 7.0 & 13.5 & - \\
\hline & & 上 & 87.0 & 76.6 & 67.4 & 57.7 & 48.1 & 38.6 & 29.4 & 18.4 & 25.1 \\
\hline & 全被験者 & 下 & 84.3 & 72.6 & 64.6 & 54.2 & 43.5 & 32.6 & 21.5 & 4.9 & $3.1^{*}$ \\
\hline & & PSE & 85.7 & 74.6 & 66.0 & 56.0 & 45.8 & 35.6 & 25.2 & 11.7 & - \\
\hline & & RAN & 1.4 & 1.5 & 1.9 & 2.2 & 3.5 & 3.9 & 5.6 & 11.1 & - \\
\hline
\end{tabular}

*印はテスト資料の最低へーズ值であるために，実際の下弁別閾はこの值より低いと考えられる。上：上 方弁別閾，下：下方弁別閾，PSE：主観的等価点，RAN：不確定範囲，ただし，全被験者欄の RAN は 各被験者の平均値 
実験の環境は, 視感比色を行う場合に準じて, 日本色研事業侏製標準型比色検査照明器 CS 802 型を用いた(図 2 )。この照明器は上部に 4 本の 20 $\mathrm{W}$ 超高演色型蛍光灯が設置されており, 資料をほ ば 2,000 ルクスの明るさで真上の方向から下向き に照明する。なお，正面の壁は黒色であり，左右 と底面は明度 7 の無彩色である。実験に際して, 被験者はテストカードを照明器内に, 上方からの 照明光束に対して 45 度, しかも自分の視線に対し て正対するように保持して観察する（図 3 ）。

被験者は 18～50 歳の男女 7 名であり,特に色覚 異常はない視覚の健常者である。

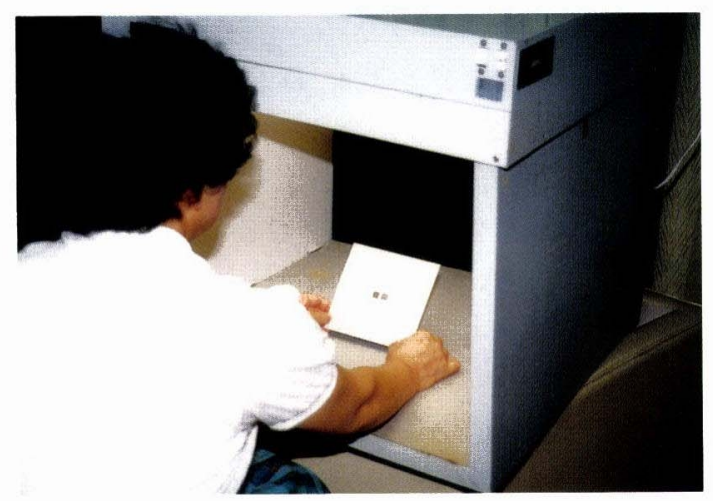

図2日本色研事業怢製標準型比色検査照明器 CS 802 型。内部に極限法へーズ差識別カードを 保持して観察する。照明光はフィルターにより 上部から垂直万向に照射する

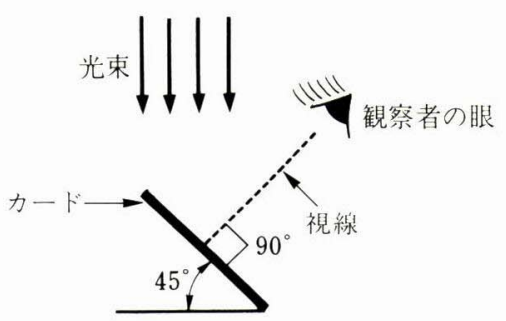

困 3 観察者の視線と光束がテストカー ドとなす角度。JIS Z 8723 表面色の 観察方法に準拠し, カードと光束は 45 度, カードと眼は 90 度

\section{2. 第 2 実験}

1) マグニチュード推定法

極限法のカードと同様の構造であり，へーズ值 $55.0 \%$ （実測值 56.5\%）を基準刺激とし，不透明 感指数 40 とする。これと併置して提示刺激があ $\eta$ ，基準刺激との不透明感の違いを比例的に評価 し，指数を口答させる。提示刺激のへーズ值は $5.0 \%$ を最低として，10\%違いで $85.0 \%$ まで 9 種 ある。提示刺激のテスト順はへーズ值の大きさに は無関係でランダムである。被験者は，極限法の 成績で選ばれた 3 名のパネルで, 実験環境は極限 法の場合と同じである。

\section{2 ) 絶対判断法}

極限法カードの系列刺激を取り除き, 標準刺激 だけにしたものを用いた。透明感のカテゴリーを 7 段階（表 2 ）に言葉で表した用紙を目の前に置 き, 手渡されたカードの刺激がカテゴリーのいず れに相当するかを口答する。被験者ならびに実験 環境はマグニチュード推定法の場合と同一であ る。このテストは, 同一人に 1 日 1 回, 5 日にわ たって計 5 回行った。

表 2 絶対判断法による尺度カテゴリー

$$
\text { カテゴリー }
$$
1.ほぼ透明といえる
2. 透明感が非常に強い
3. 透明感がはっきりある
4. 中ぐらいの透明感である
5. 透明感が少ない
6. 透明感が非常に少ない
7.ほぼ不透明といえる

\section{3 ) ヘーズの測定}

各資料の測定は，スガ試験機㑣製直読へーズコ ンピューターHGM-2 DP 型(困 4，5）を用いた。 このへーズメーターは, 直径 $25 \mathrm{~mm}$ 以上の大き さの資料を本体内に入れ，スイッチを入れるだけ で, 全光線透過率, 拡散光透過率, 平行光線透過 率，へ一ズ值を全自動的に演算部で算出し，プリ 


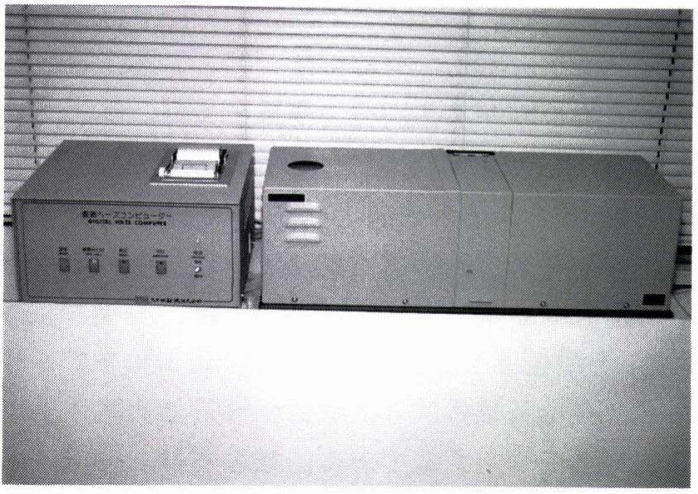

図 4 スガ試験機侏製直読へーズコンピューター HGM-2 DP 型。測定時間は 5 秒以内

ントアウトする。

\section{III. 結 果}

\section{1. 上方弁別闘, 下方弁別闘, 不確定範囲}

人の官能には，不確定範囲 (不定帯) といわれ るものがあり，この範囲のなかで刺激を変えても 官能はその変化を知覚できない13)。本実験におい ては, へーズ值の大きいほうから小さいほうへ変 えていった場合に透明性が等価と知覚した，ある いは違いが分からなくなった時の值が上方弁別閾 であり，へーズ值を低いほうから高いほうへ変え ていった時の值が下方弁別閾である。この両方の
值の間では，その被験者は標準刺激との違いを知 覚することはできないことになり，その幅を不確 定範囲という。

全被験者について，9種類の標準刺激に対する 各測定值を表 1 に示す。用意した系列刺激の最低 が $3.1 \%$ であり，下方弁別䦨を調べる場合の $5.5 \%$ の標準刺激については, 最も離れた刺激のこの価 でも見分けがつかなかった被験者が 5 人（A， C, $\mathrm{D}, \mathrm{F}, \mathrm{G})$ いた。これらの被験者の場合は，下方 弁別閾は $3.1 \%$ 以下であるが詳細は不明で, 不確 定範囲は求められない。不確定範囲の大きさは, 低へーズ值のものほど大きく, 高へーズ值になる につれて小さくなるという傾向が被験者全員に共 通しているが個人差は大きい。すなわち, ヘーズ 值 50\%以上の高へーズについては, 不確定範囲の 平均は被験者 $\mathrm{A}, \mathrm{F}$ が1.4, D が1.5, B が 1.6, Cが1.9, Eが2.0, Gが2.3であった。一方, 一一 ズ值 $50 \%$ 未満の低へーズについては, F が4.6, A が5.0, D が $5.2, \mathrm{~B}$ が $6.3, \mathrm{C}$ が 6.7 , Eが 6.8 , Gが 7.7 であり，高へーズに対して成績のよい者 は低へーズに対しても好成績であった。主観的等 価点と実測值のずれが小さく，しかも不確定範囲 の幅が狭い者 $\mathrm{A}, \mathrm{D}, \mathrm{F}$ を成績優秀として, 次の標 準光透過票作成のための官能検査パネルとして選 出した (表 1,3 )。

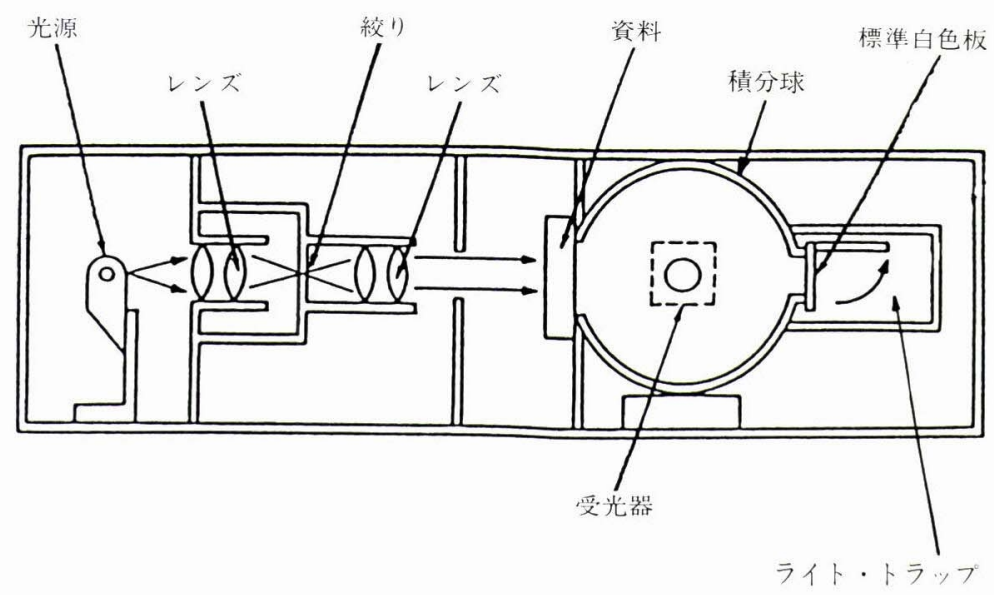

図 5 ヘーズメーターの模式図 
表 3 ヘーズ值別不確定範囲

\begin{tabular}{c|c|c}
\hline \hline \multirow{2}{*}{ 被験者 } & $\begin{array}{c}\text { 高へーズ值の平均 } \\
\text { 不確定範囲 }(\%)\end{array}$ & $\begin{array}{c}\text { 低ヘーズ值の平均 } \\
\text { 不確定範囲 }(\%)\end{array}$ \\
\hline $\mathrm{A}$ & 1.4 & 5.0 \\
$\mathrm{~B}$ & 1.6 & 6.3 \\
$\mathrm{C}$ & 1.9 & 6.7 \\
$\mathrm{D}$ & 1.5 & 5.2 \\
$\mathrm{E}$ & 2.0 & 6.8 \\
$\mathrm{~F}$ & 1.4 & 4.6 \\
$\mathrm{G}$ & 2.3 & 7.7 \\
\hline
\end{tabular}

高へーズ: $55,65,75,85 \%$

低へーズ：45，35，25，15\%

\section{2. マグニチュード推定}

先の実験により，へーズ差の識別能力が優れて いた 3 名の官能検査パネルを対象として行ったマ グニチュード推定法の実験結果を表 4 に示す。 ヘーズ值 55.0\%は基準刺激であり，その不透明感 の指数を 40 とするように指示した。ただしスコア の上限，下限については，パネルが自由に感覚に
基づいて評価するのであり，特に取り決めはして いない。ただし，不透明感が感覚的に 2 倍大きい と感じればスコアは 80 とし，3 倍ならば 120 , 半 分なら 20 と比率で表すように指示してある。

3 人のパネルの合計 15 回のテストから中央值 を求め, それぞれの刺激（S）に対するマグニ チュード推定值 $(\mathrm{R})$ とした。 $\mathrm{S}$ と $\mathrm{R}$ の関係を図 6， 7 に示す。グラフの横軸は刺激 S の対数をとり, 縦軸は反応 $\mathrm{R}$ であるが, 図 6 では普通目盛りに, 図 7 では対数目盛りにとってある。図 6 において 結果はほぼ二次曲線となり, 図 7 においてはほぼ 直線的になった。

\section{3. 絶対判断}

同じ 3 人のパネルについて，9種類の資料の透 明感を 7 つカテゴリー（表 2 ）に分類するテス トを行った。カテゴリ一標識番号はデー夕整理上 必要で，パネルには番号のないものを提示した。 番号がついていると, 比率尺度や間隔尺度と勘違 いしかねないからである。各パネルが 5 回づつ, 延べ 15 回の実験結果の平均值を求めて, その刺激

表 4 ヘーズ刺激に対するマグニチュード推定

\begin{tabular}{|c|c|c|c|c|c|c|c|c|c|c|c|c|}
\hline & \multirow{2}{*}{\multicolumn{2}{|c|}{$\begin{array}{l}\text { 目標値 } \\
\text { 実測値 }\end{array}$}} & 85.0 & 75.0 & 65.0 & 55.0 & 45.0 & 35.0 & 25.0 & 15.0 & 5.0 \\
\hline & & & & 85.3 & 75.6 & 66.4 & 56.5 & 45.9 & 35.6 & 26.5 & 13.4 & 6.1 \\
\hline & \multirow{5}{*}{ A } & & 1 & 90 & 70 & 50 & 40 & 30 & 15 & 10 & 3 & 1 \\
\hline & & 回 & 2 & 90 & 65 & 50 & 40 & 25 & 20 & 10 & 3 & 1 \\
\hline & & & 3 & 90 & 70 & 60 & 40 & 30 & 15 & 10 & 5 & 1 \\
\hline & & 数 & 4 & 90 & 70 & 60 & 40 & 30 & 15 & 10 & 5 & 1 \\
\hline - & & & 5 & 90 & 60 & 55 & 40 & 20 & 20 & 10 & 5 & 1 \\
\hline \multirow{5}{*}{ ネ } & \multirow{5}{*}{$\mathrm{D}$} & & 1 & 85 & 75 & 60 & 40 & 30 & 15 & 8 & 2 & 1 \\
\hline & & 回 & 2 & 90 & 80 & 65 & 40 & 30 & 15 & 10 & 4 & 1 \\
\hline & & & 3 & 90 & 80 & 70 & 40 & 20 & 10 & 5 & 2 & 1 \\
\hline & & 数 & 4 & 100 & 90 & 75 & 40 & 25 & 10 & 5 & 3 & 1 \\
\hline & & & 5 & 100 & 90 & 65 & 40 & 30 & 15 & 5 & 3 & 1 \\
\hline \multirow{6}{*}{ ル } & \multirow{5}{*}{$\mathrm{F}$} & & 1 & 95 & 70 & 50 & 40 & 30 & 20 & 10 & 5 & 2 \\
\hline & & 回 & 2 & 90 & 85 & 50 & 40 & 30 & 20 & 10 & 5 & 3 \\
\hline & & & 3 & 90 & 85 & 40 & 40 & 25 & 15 & 10 & 3 & 1 \\
\hline & & 数 & 4 & 85 & 80 & 45 & 40 & 20 & 15 & 10 & 3 & 1 \\
\hline & & & 5 & 95 & 75 & 40 & 40 & 20 & 15 & 10 & 5 & 1 \\
\hline & & 中央 & & 90 & 75 & 55 & 40 & 30 & 15 & 10 & 3 & 1 \\
\hline
\end{tabular}




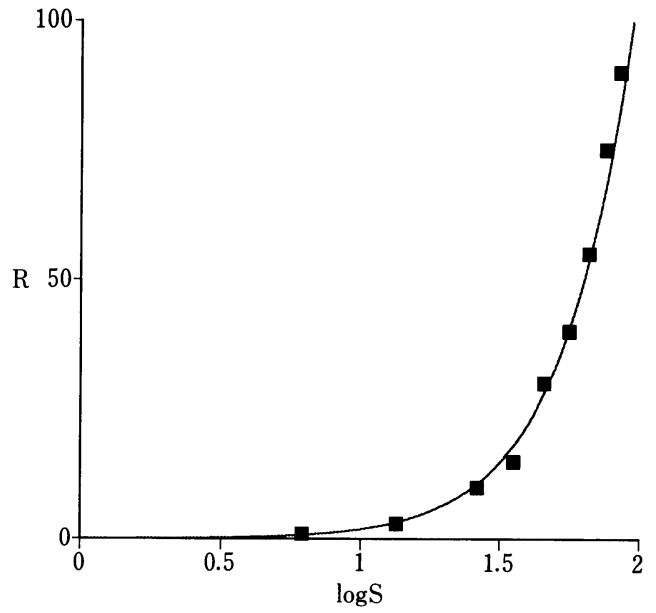

図 6 ヘーズとマグニチュード推定との関係を 片対数軸で表示

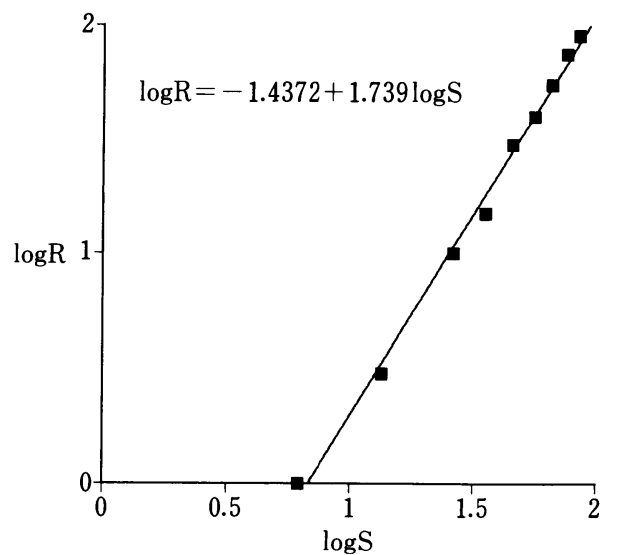

困 7 ヘーズとマグニチュード推定との関係を 両対数軸で表示

表 5 ヘーズ刺激に対する各被験者の絶対判断の結果

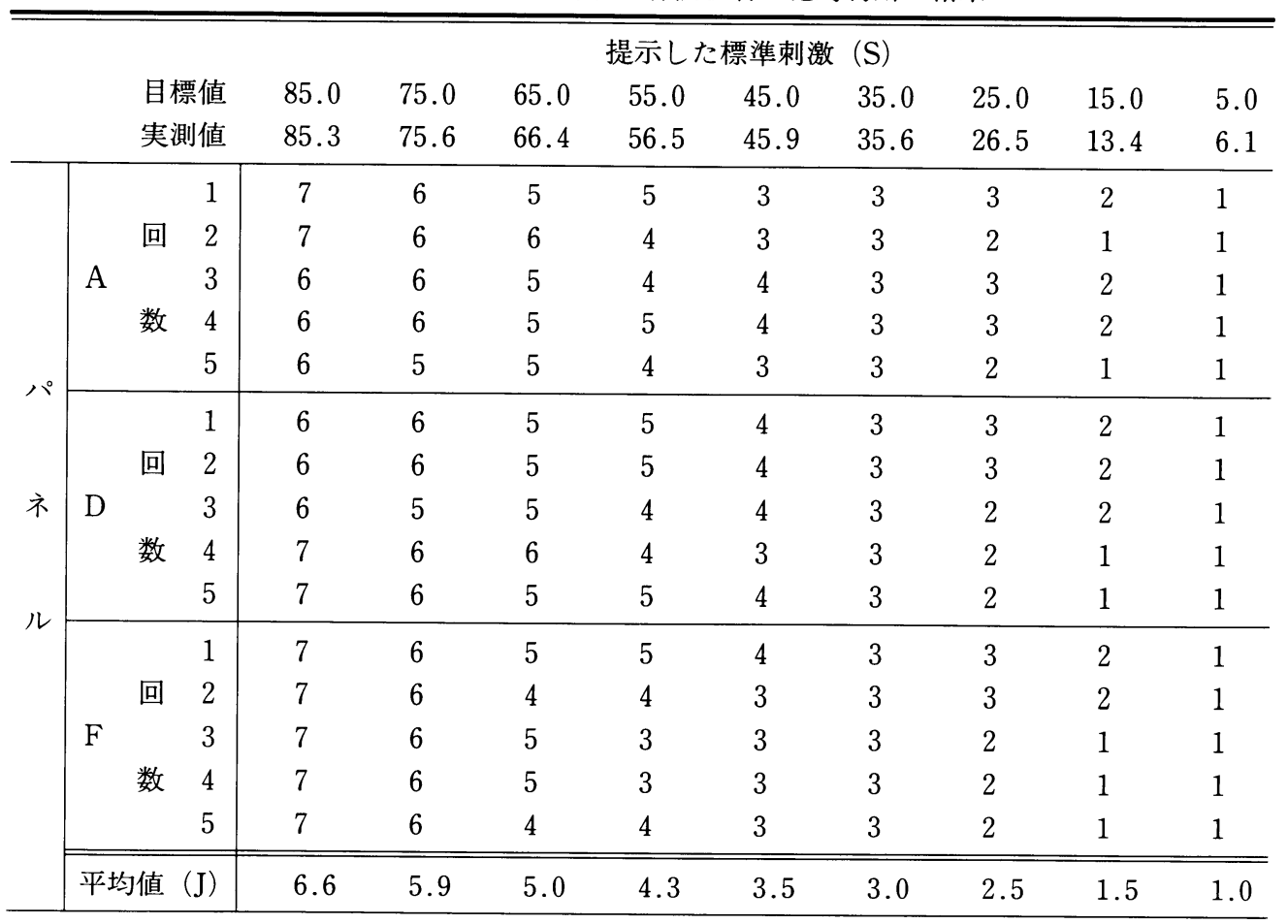


に対する反応 Jとした（表 5 ）。この尺度カテゴ リーは，言葉で表現されていても透明感という連 続した感覚を対象としており，尺度カテゴリーに つけた数字は表 6 に示すような単なる名義尺度や 順序尺度ではない。したがって，小数点以下の数 值が算出されても意味をもつ。

\section{IV. 考察}

歯冠色を目視で測るように，歯の光透過性を観 察者が視覚を頼りに測ることができるのであろう か。本研究は主観的な透明感の感覚の大きさと, その測定に用いる透明感の感覚尺度について考察 する。感覚・知覚を科学の 1 現象として捉えよう とすると，測定ということが必然となる。すなわ ち, 測定対象となる量があり，この量をなんらか の計測法あるいは計測機器を用いて測定しなけれ ばならない。一般の計測器は，量を数で現すため に用いられるものであり，そこでは問題になって いる量と得られた数の間には 1 对 1 関係が存在し なければならず，測定とはこのようにある量と数 との間に一義的な对応関係を確立する方法であ る。したがって，歯冠の光透過性を測定できるか どうかということは, 歯冠の光透過性という物理 的な量に対して, 透明感という感覚量を数で対応 させうるかどうかという問題に帰着する。

\section{1. 官能検查パネルについて}

官能的に測定または検査, 評価する人を官能検 査パネルまたはパネリストという ${ }^{14)}$ 。官能検査パ ネルは官能的品質特性の測定機器の役割を果たさ なければならないので，問題点の最大のものは感 覚の個人差である。この個人差には生理的能力の 個人差と心理的能力の個人差がある。生理的能力 には，感覚器の先天的，後天的欠陥がある場合は 論外として, 刺激閾や弁別閾で表される知覚の鋭 敏さの程度をはじめ，類似刺激の種類によっても 鋭敏さが変わらないことが要求される。また，心 理的能力としては判断基準の妥当性と安定性とが ある。標準・限度見本が与えられれば，その見本 からの差を検出する能力と, 差を定量的に評価す る判断が妥当でなければならない。また，日時を
変えても同じ対象に対しては，同じ判断基準を維 持し，偏りのない評価ができる安定性も要求され る。

検查パネルを選択するための一つの基準は，生 理的能力である。人間の官能の生理的能力を数量 的に捉える方法は，その人の刺激間あるいは弁別 閾を測定することが必要になる。刺激閾は検査パ ネルが感じることができる最小の量であり，弁別 閾は刺激の強さを変化させた時に，その変化を感 じる最小の差ということになる。視感比色法によ る測色では，標準色票を用意して対象と色が等価 な色票を探してその対象の色としている。透明感 も視覚情報の一つであり，へーズ值が異なる何種 類かの標準へーズ票（へーズ・スケール）からな るへーズガイドを用意して，視感によって対象物 のへーズ值を測定することは可能と思われる。こ のような場合には，刺激閾よりも弁別間の小さな 検查パネルが能力が優れていることはいうまでも ない。本実験では，後に標準へーズ票を作成する ときに範囲をどうするか，ステップをどれほどに して 1 組のへーズ票を構成すべきかという情報を 得るための協力者になることから, 被験者のなか から最も成績のよいものを選び出さねばならな い。

\section{2. パネルのヘーズ差識別能を測る極限法 (method of limits)}

標準刺激と増加または減少する比較刺激を実験 者があらかじめ決めておき，順番に一つづつ提示 してパネルに比較させ，やはりあらかじめ決めら れた選択肢，すなわち「違いがある」または「違 いがわからない」，「等しい」のいずれか反応を選 択させる。透明感の弁別閾を測定する場合に，一 定の透明度（ヘーズ）のプラスチック・シートを 標準刺激として，またそれより明らかに透明なプ ラスチック・シートを比較刺激として提示され， 透明度に違いがあるかどうかを識別する。違いが あると認めた場合，これよりわずかに透明度の低 いものを次の比較刺激として提示する。このよう にして標準刺激は変わらないが，比較刺激が徐々 に不透明になって行き，パネルが「違いがわから 
ない」とはじめて応えた時点でこの刺激系列を打 ち切る。この場合は, 透明感でいえば下降系列(下 降刺激）であり，へーズでいえば上昇系列（上昇 刺激）である。

求める測定值は反応が変化した前後の 2 つの刺 激の間にあると考えられるので，2つの刺激の中 央值を算出し，その系列の測定值とする。そして， 上昇，下降両系列の測定值の平均をもって求める 主観的等価点 (point of subjective equality : P. S. E.)（ときに判断值と呼ぶ）とする ${ }^{10) 。 な お ， こ ~}$ の方法は極小変化法 (method of minimal changes) とも呼ばれるように, 刺激は必要な限り 少しづつ変化させることが重要であり, 本実験に おいては，ポリプロピレンシートで調整して 1 度 の変化量を最大でへーズ值 $1.0 \%$ にどめた。ま た，上弁別闇と下弁別閾の間の範囲はへーズ值を 変えても透明感に変化がないことから不確定範囲

(不定帯) といえる。実験から得られた 9 種の標 準刺激に対する不確定範囲の大きさをグラフに示 すと図 8 のようになる。不確定範囲は $5.0 \%$ の場 合に計算不能であったので，それを除外すると $15.5 \%$ の最低へーズ值の場合に $11.1 \%$ と最大で, へーズ值が高くなるにつれて小さくなり， $85.3 \%$ の最高へーズ值の場合は $1.4 \%$ と最小にとどまっ

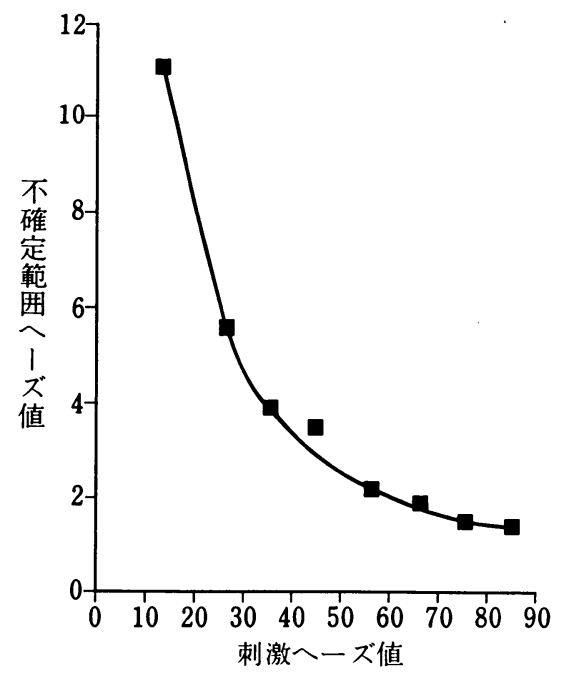

図 8 ヘーズ値に対する不確定範囲の大 きさ
た。

極限法は刺激間, 弁別閾, 主観的等価值のいず れの測定にも用いることができる。この方法の最 大の特徵は刺激の変化が小から大, あるいはその 逆の大から小へと段階的に行われる点である。し たがって，被験者は刺激がどのように並んでいる かを容易に知ることができるので，手のうちの多 くの部分が被験者に知られていることから, 半知 手続き（method with part knowledge）と呼ばれ ている ${ }^{10)}$ 。そこで, 系列刺激の何番目の刺激で判断 が変化したかを被験者にわかりにくくするため に，小から大，大から小への 2 種類の系列を用い るとともに, 各系列のスタート点を被験者により， また上昇, 下降各 6 回づつ繰り返し実験において いろいろに変化させた。このようにして，半知の 程度を減ずることによって, 実験結果の正当性を 高めている。なお，弁別閾を求める実験では，同 じ刺激に对して常に一定の反応を示さないのが常 である。6 回づつの繰り返しにより，上弁別閾， 下弁別闇とも測定值が 6 個得られるが，最終的に は 50\%弁別できる場合の刺激の変化量をもって 弁別閾とする。

この方法には実験手続き上避けられない誤差が 存在する。すなわち, 恒常誤差 (constant error) として実験慣れによる誤差 (error of habituation）と期待誤差（error of expectation）を含ん でいると考えられる ${ }^{10)}$ 。慣れの誤差は, 被験者が慣 れにより同一の判断を不当に繰り返し，普通より 遅く変化に気が付くという傾向から生じる。しか し，この誤差は小から大，大から小への両方向の 刺激変化において，その大きさが等しく出ると考 えられることから，上昇系列と下降系列の 2 方向 の刺激変化の平均值を求めることによって互いに 相殺されているはずである。期待誤差は，被験者 が系列中の変化が今度こそ起こるはずだとか，ま だまだ起こらないだろうと期待する傾向から生じ る。被験者にこの期待要因が作用すると, 系列中 の変化が普通より早く出たり, 遅く出たりするが, この誤差も慣れの誤差の場合と同様に, 小から大, 大から小への 2 方向の刺激変化を用いることに 
よって相殺することができると思われる。

被験者のなかから，優秀な識別能をもっている とするための条件は, (1) PSE (主観的等価点) と 実測值との差が小さいこと, (2)不確定範囲が狭い ことである。(1)の PSE と刺激の真の価との差に ついては,ほとんど被験者間に差はみられないが, (2)の範囲については個人差が大きい(表 1 )。本実 験の成績から, 被験者 $\mathrm{A}, \mathrm{D}, \mathrm{F}$ を官能検查パネル として選出した。

\section{3. 歯の透明感の測定法について}

歯冠を観察した時に，歯冠表面が光で照射され ると，一部はその表面で反射されるが，残りは工 ナメル質に入射する。この入射光は, 歯冠内部で 吸収されて減衰するもの，散乱によってその方向 を変えるものなどに分かれるが残りのものが内部 反射によって再び入射面に逆戻りし，表面から外 へ出て反射光として観察者が認めるところとな る。こちら側の光が物体を通過するということは, 物体の向う側からの光もこちらへ通過するとい う，すなわち光が逆進するということで物体の透 過光を関知し, 透明感がでる。

口腔内の歯の場合は, エナメル質そのものだけ でなく，エナメル層に隣接した象牙質の色が透過 して観察されたり，切端付近の象牙質の裏打ちの ないところでは, 口腔内の暗さを透視することか ら歯冠の透明感が生じる。それらを定性的, 定量 的に分析することは, 理論的にはクベルカ・ムン ク15)の理論によって可能ではあるが, 実際面では 現段階では実現していない。そこで著者は，目視 によって歯の透明感の定量的計測を行うことが試 みられるべきであると考えた。それは，視感比色 法によって物体の色の測定を行うことと同様であ ク，まず必要なものは標準色票に相当する標準光 透過票である。これは, あらかじめ透明度（また はへーズ值）の判明しているものを数種用意して おき，目視によって測定対象と当価なものを選び 出し，その価をもって対象の透明度（または最り 度）とする。また，等価なものがない場合には，

目測補間法によって測定值を求める。

光透過性のエナメル質や象牙質で構成されてい
る歯冠も，確かに透明度を考えることができる。 透明度は物質内を通過する光の量を主として考え るものであるが，その逆に，どれほど光が通りに くいかということに主眼を置くへーズ(haze)（曇 り值）という概念がある。この両者は，裏表の関 係であり，へーズ值が低いということは透明性が 高いということと同じになる。

1 ) 感覚の測定

感覚の測定ということになると, 生理学的な立 場と心理学的な立場に分かれるが, 臨床に則して 本実験は多分に心理学的な手法によるところが多 い。心理学的な立場から, Stevens ${ }^{16)}$ は感覚には質 的な感覚と量的な感覚があるとし，それぞれメ夕 セティック連続体 (metathetic continuum) およ びプロセティック連続体 (prothetic continuum) と区別して呼んでいる。たとえば，前者には音の 高さがあり, 後者には明るさ, 重さ, 音の大きさ などがある。メタセティックなものの例として音 の高さについてみると, 音の高さの違いとは物理 的な刺激の周波数の違いである。周波数の違いは, 蝸牛基底膜の異なる場所を興奞させ，このように 刺激の変化が異なる場所の興奮につながるような 場合がメ夕セティックすなわち質的であり, 定量 的な測定に不向きとなる。一方, 音量は音の物理 的な強さの増減に対応していて, 蝸牛基底膜の同 一の場所の興奮の増減に対応しているから, 感覚 の計量が可能となる。

マグニチュード推定法は Stevens が考案した 方法で，人間は自分の感覚を量的に把握できると 仮定し, 感覚量を定量的に報告させる方法である。 被験者には標準刺激（ときに modulus と呼ばれ る）と比較刺激 (系列刺激) の 2 種が提示され, 被験者は標準刺激に対する比較刺激の感覚量を両 者の比として報告する。標準刺激の大きさを 100 とか 10 と仮定するといった決まりはないが， 5 〜85\%までの一通りの全系列を通じて同じ值とし なければならない。そこで，比率計算に都合のよ い端数のない数值として40にするよう指示した。 標準刺激は全刺激系列の提示に先立って一つだけ （1回だけ）提示され，被験者が記憶した結果を 
もとに行われる場合もあるが，本実験では比較刺 激に対して毎回併置させて提示した。これは記憶 の変容によって判断の基準が変わることを防ぐた めである。標準刺激は系列刺激の刺激強度の範囲 のほぼ中央にとるのが一般的であるが，本実験は 歯冠の透明感ということがねらいであるために， ヘーズ值 $50 \%$ よりも若干歯のへーズ值の領域に 寄せて，55\%を標準刺激とした。しかし，現実の 刺激は $55 \%$ に調整することが結果的にできず，実 測值は $56.5 \%$ であった。また，刺激の 1 ステップ ごとの変化量は $10 \%$ と感覚量の最小単位の j.n.d.

(just noticible difference, 丁度可知差異, 最小 可知差異）より十分大きくとった。

結果の処理については, 被験者が報告した数値 をそのまま心理量と仮定し，全パネルの中央值を 求めたところ, 標準刺激と 8 種の変化刺激に対し てへーズ值の高いほうから順に $90 ， 75 ， 55 ， 40$, $30 ， 15 ， 10 ， 3 ， 1$ となった（表 4 ）。

2 ) 測定と尺度

歯冠を目視で観察する場合に知覚する歯の透明 感が測定の対象となるある量をもつものであるか
どうかについては議論の余地は残るが，われわれ の主観的経験からみて, 感覚のみが測定対象とな るある量をもつものと考えられる。したがって， 測定は透明感と数字との対応関係を確立する方法 を探すことからはじまる。そのためには，尺度が 必要になる。尺度は, どのような規則を当てはめ るかによって型が決まることになり，一般的な型 として名義尺度および順序尺度，間隔尺度，比例 尺度の 4 つが挙げられる ${ }^{17)}$ (表 6 )。

ヘーズ值は，次の式によって計算される物理的 な值であり，比例尺度である。

$$
\begin{aligned}
& \text { ヘーズ (量り価) } \quad(\%)=\mathrm{Td} / \mathrm{Tt} \times 100 \\
& \mathrm{Tt}=\mathrm{Td}+\mathrm{Tp}
\end{aligned}
$$

$\mathrm{Td}$ : 拡散光透過率 $(\%)$

$\mathrm{Tt}:$ 全光線透過率 $(\%)$

$\mathrm{Tp}$ : 平行光線透過率 $(\%)$

以上からわかるように，へーズとは資料を透過 した全光線透過光量に含まれる拡散光透過光量の 割合である。したがって，透明な資料ほど平行光 線透過量の割合が多く, 拡散光量の割合が少なく, 不透明な資料の場合はその割合が逆になる。しか

\begin{tabular}{|c|c|c|}
\hline $\begin{array}{l}\text { 名義尺度 } \\
\text { nominal- } \\
\text { scale }\end{array}$ & $\begin{array}{l}\text { 分類した対象や事象の命名に数字を用い, 数 } \\
\text { 字による対象や事象の同定を可能にする。特 } \\
\text { 定の数字と特定の対象は常に等しい対応関係 } \\
\text { にある。これらの数字は順序や大小関係を表 } \\
\text { すものではない。 }\end{array}$ & $\begin{array}{l}\text { 機器の型式番号 } \\
\text { 運動選手の背番号 }\end{array}$ \\
\hline $\begin{array}{l}\text { 順序尺度 } \\
\text { ordinal- } \\
\text { scale }\end{array}$ & $\begin{array}{l}\text { 順位をつけることが可能な場合，その順位に } \\
\text { 対応させて割り当ててつくり出された尺度。 } \\
\text { 大小・優劣などの関係を表すが, 順位間の差 } \\
\text { の大きさについては情報を提供しない。 }\end{array}$ & $\begin{array}{l}\text { マラソンの着順 } \\
\text { 石のモースかたさ }\end{array}$ \\
\hline $\begin{array}{l}\text { 間隔尺度 } \\
\text { interval- } \\
\text { scale }\end{array}$ & $\begin{array}{l}\text { 分割尺度ともいわれ，その尺度の原点は比例 } \\
\text { 尺度とは違い，任意に定義される。したがっ } \\
\text { て，この尺度間の差あるいは距離のみが意味 } \\
\text { をもつ。 }\end{array}$ & 体温計の目盛り \\
\hline $\begin{array}{l}\text { 比例尺度 } \\
\text { ratio- }^{-} \\
\text {scale }\end{array}$ & $\begin{array}{l}\text { ある一定の大きさを基準にして, 他のすべて } \\
\text { の大きさをそれとの比の形で表したもの。尺 } \\
\text { 度值の原点が絶対的なゼロ点として定義され } \\
\text { る。 }\end{array}$ & $\begin{array}{l}\text { 重さ・長さの目盛 } \\
\eta\end{array}$ \\
\hline
\end{tabular}

表 6 尺度の種類と特徵 
し，歯冠の透明感に限って考えると，この感覚を 表す尺度は，攝氏や華氏で表される温度感覚の目 盛りのように用いられるものであり，間隔尺度を 構成するように思える。したがって，刺激の物理 的な大きさと感覚の大きさの間の関係の法則とし ての精神物理的法則を見い出すために，Fechner あるいは Stevensの式のどちらによってより正 確に説明されるかを吟味する。

(1) Fechner の対数法則

Fechner は刺激の物理的な大きさ $\mathrm{S}$ と感覚の 大きさ $\mathrm{R}$ との間に成立する法則として次式を提 唱した。

$$
\mathrm{R}=\mathrm{a} \log \mathrm{S}+\mathrm{b} \quad(1 \text { 式 })
$$

ここで $\mathrm{a}, \mathrm{b}$ は定数である。この式は Fechner の 法則 (Fechner's law) あるいは jnd 尺度 (Fechner' s scale）と呼ばれ， R は $\log \mathrm{S} の 1$ 次関数になる ことを予想する。Fechnerの法則は Weber の法 則から誘導されている。この Weber の法則とは, 感覚における丁度可知差異 (jnd， $\Delta \mathrm{S}$ ) は刺激の物 理的大きさ $\mathrm{S}$ と比例して大きくなるというもの である。Fechner は 1 単位の jnd を刺激に加える ごとに感覚は一定の大きさで大きくなると仮定し た。この Fechner の仮定と Weber の法則から(1) 式は導出される。

(2) Stevensのベキ関数

一方, Stevens は, 刺激の物理的大きさ $\mathrm{S}$ と感覚 の大きさ $\mathrm{R}$ との間の精神物理的法則として,

$$
\mathrm{R}=\mathrm{kS}^{\mathrm{n}}
$$

なるべキ関数を提唱した。

ここで, $\mathrm{k}$ と $\mathrm{n}$ は定数である。Stevens は数多く の感覚樣相において(2)式の関係が成り立つことを 見い出し，しかも，それぞれの感覚特性は刺激 S のべキ指数 $\mathrm{n} の$ 值によって表されることを明ら かにした。

この(2)式の両辺の対数をとると，

$$
\log \mathrm{R}=\log \mathrm{k}+\mathrm{n} \log \mathrm{S} \quad(3 \text { 式) }
$$

となる。この式は縦軸に $\log \mathrm{R}$ をとり, 横軸に $\log$ $\mathrm{S}$ をっっグラフを書くと勾配 $\mathrm{n}$ の直線になるこ とを意味している。

マグニチュード推定法の実験結果の表 4 をもと
に， $\mathrm{R}$ と $\log \mathrm{S}$ の関係， $\log \mathrm{R}$ と $\log \mathrm{S}$ の関係を 図 6 と図 7 に示す。図 7 よりマグニチュード推定 法の実験結果は $\log \mathrm{R}$ と $\log \mathrm{S}$ の間に明らかに直 線関係が認められる。しかし，図6では $\mathrm{R}$ と $\log \mathrm{S}$ の間には直線関係ではなく，下に凸の曲線関係と なっている。これらのことは，刺激をへーズ值で 表した透明感の感覚は，(1)式に示される Fechner の法則では $\mathrm{R}$ と $\log \mathrm{S}$ は 1 次関数であり, グラフ は直線的になるはずである。したがって，本実験 結果はFechnerの法則への当てはまりは不十分 であり，Stevensの(2)式のべキ法則のほうがよく 当てはまることを示している。なお, 図 7 の回帰 直線の式は次のようになる。

$$
\log \mathrm{R}=-1.4372+1.7396 \log \mathrm{S}
$$

これより, Stevensのべキの值 $\mathrm{n}$ は 1.74 であ る。

3 ) 標準光透過票の範囲とステップ

評定尺度法 (rating scale method, 絶対判断法) という手法がある。この心理尺度は，ある評価に 関して一次元の心理連続体が存在すると仮定され る。この心理尺度は感覚尺度であると仮定され， この尺度を刺激強度の物理值によって構成しよう と試みるものである。

パネルは提示された刺激に対する反応を, 数段 階に分けられた反応尺度上の 1 段階を選択すると いう方法によってなされる。この反応尺度は仮定 された心理尺度であり，連続体のうちいくつかの

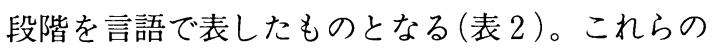
選択肢は，独立した 7 つ項目があるのではなく， 透明性を感じる心理連続体上の 7 つの点を示した ものと考える。さらに, 便宜上この 7 つの点は等 間隔であると仮定して反応を求める。この仮定は, 反応を行うパネルにも前もって十分知らしめてお く。評定尺度は連続体であるが, 被験者は提示さ れた選択肢以外の点は選択できない。このためパ ネルの感じる心理量がある選択肢と次の選択肢の 中間に存在する場合がある。しかし，パネルは中 間の值を選択することが許されず，どちらか近い ほうを選択することを強制されることになる。こ の点に関しては, 試行の繰り返しによる選択率に 
反映され, 選択確率が 2 つの選択肢にほぼ同数 (同 率）に分かれるような刺激強度は，両者の中間に 心理評定量があると考えられる。

臨床においては, ポーセレン・ワークの技工指 示書などの記載において,「切端部の透明感を少な く」といった言葉でその程度を表現している。パ ネルの絶対判断の結果（表 5 ）をみると，その絶 対判断はほとんどの透明度についてカテゴリーの 標識番号が 3 と 4 というように 2 種出てくる。こ れは, パネルが違えば判断が異なるという個人差 とともに，同一パネルでも試行日が違えば判断が 異なるいわゆる日間変動を表している。特に, へ一 ズ值が 50,60 代の歯の透明感で中心的な值につい ては, 透明感がはっきりある, 中ぐらいの透明感 である，透明感が少ないの 3 種，あるいは，中ぐ らいの透明感である, 透明感が少ない, 透明感が 非常に少ないの 3 種も登場している。このことは 透明感を伝達するのに，言葉だけではほとんど正 確を期待できないということになり，臨床的なス ケールの早い完成が待たれることの証明になる。

歯冠用標準光透過票の光学的な設計基準は, 範 囲の決定とステップの大きさである。まず，範囲 については, 歯冠の場合は「透明感がはっきりあ る」ところから「ほぼ不透明といえる」まであれ ばよい。絶対判断の結果をみると(表 5 ), ヘーズ 值 $13.4 \%$ のもは, カテゴリ一標識番号の 1 と 2 であり, 平均 1.5 ということは, 歯冠用としては 透明性が強すぎる。 $26.5 \%$ につてはカテゴリー 標識番号 2 と 3 であり，「透明感がはっきりある」 という評価が出てくる。そこで, 標準光透過票の 最低へーズ值としてはこの付近にすればよい。ま た，高へーズのものは，実験中最高のへーズ值で ある $85.3 \%$ でも標識番号は 7 のほかに 6 が出て, 平均は 6.6 にとどまっている。したがって，もう 少し高へーズ值のものまで用意するほうがよい。

次に，ステップの大きさについては，隣り合う 標準光透過票の不確定範囲が重ならないように, へーズ差をとることと視感的に均等へーズ差, す なわちマグニチュード推定法の実験をもとに間隔 尺度となるように揃えることである。不確定範囲
は，その中央に主観的等価点があり，それから高 ヘーズ值側と低へ一ズ值側に均等に分布している と考之られる。したがって，不確定範囲の 2 分の 1 の大きさまでは，完成した一連の標準光透過票 にヘーズ值差があっても，識別できないことから 許容範囲とする。この許容範囲の大きさについて は，図 8 から読み取れる。以上の条件を満たすよ うに，表 5 および図 8 から目標とするへーズ值, 許容範囲を決定した（表 7 ）。

表 7 標準光透過票の理論値と許容差

\begin{tabular}{ccc|ccc}
\hline \hline \multicolumn{2}{c}{ 番号 } & ヘーズ值 許容差 & \multicolumn{3}{|c}{ 番号 } \\
\hline 1 & 25.2 & 2.8 & 10 & 67.1 & 1.0 \\
2 & 31.8 & 2.2 & 11 & 70.5 & 0.9 \\
3 & 37.5 & 1.8 & 12 & 73.8 & 0.9 \\
4 & 42.6 & 1.5 & 13 & 77.1 & 0.9 \\
5 & 47.3 & 1.3 & 14 & 80.2 & 0.8 \\
6 & 51.7 & 1.3 & 15 & 83.2 & 0.8 \\
7 & 55.9 & 1.2 & 16 & 86.2 & 0.8 \\
8 & 59.8 & 1.2 & 17 & 89.0 & 0.7 \\
9 & 63.5 & 1.1 & 18 & 91.9 & 0.7 \\
\hline
\end{tabular}

\section{4. 残された問題点}

\section{1) 写像性について}

透明感を左右する因子としては, 光透過性のほ かに写像性がある ${ }^{18)}$ 。写像性というのは, 透かして みえる像の鮮明度のことである。これは像のボケ 具合という表現が日常なされているものである が，同じへーズ值のものであっても，その物体を 通してみえる向う側のものの輪郭の鮮明さに違い が出ることが多い(図 9)。そのようなことは, 単 に写像性という物理的な特性からだけでなく, 半 透明物体と向う側のものとの距離によっても違い が出る。一般的には, 密着しているほうが, 離れ ているよりは像が鮮明になる。歯冠の透明感につ いては，その後方の物体の形をみるということを 考慮する必要はなく, 写像性の問題はひとまず先 送りをした。しかし，写像性の関わる物理的な光 学的な特性が全く透明感に無関係であるという証 


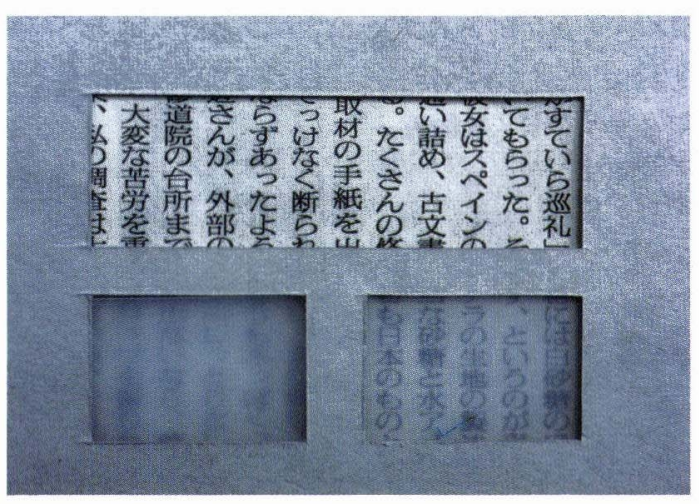

困 9 写像性の違いの実例。上の横長は素通し。左下 は写像性が低く, 右下は写像性がよい。へーズ值 は左下 54.8 , 右下は 54.4 とほぼ同じ

明はなく，いずれ手をつけなければならないと考 えている。

2）視感による計測誤差

(1) 個人差

不確定範囲の幅に個人差が大きいことは，表 1 に明らかになっている。また，絶対判断について も，同一人が試行のたびに一定の刺激に対して 違った評価をすること，そのうえ評価が他人と異 なることが問題になる(表 5 )。これら一連の問題 は，視感比色法で測色する場合にも問題視されて いる。透明感の識別能も色弁別の場合と同じよう に類似した能力を磨くことによって，期待される 能力にトランスファーする学習効果が大きく働い ていると仮定すれば，トレーニングによってある 程度の成績の向上は期待される ${ }^{19)}$ 。しかし, 透明感 の場合は，どのようなトレーニングが効果的であ るか全く知られていない。絶対判断法の実験の上 うに，対象をどのカテゴリーに分類するかという 操作においては，もともと価值付けには個人差が あるものである。それを専門にしている人が判断 したからとか，大勢の人の納得が得られたからと いったことが正しいことの保証にならないもので あり，個人差が誤差であると決めつけてかかれな いであろう。しかし，価值付けが一様でない場合 に誤差が入っているとか，当てにならないと思う
人が多いのは現実問題である。大勢の人の感じ方 が一様であると仮定すること，また一様な結果が 得られないからといってそれを一様になるように する方法を考えることなどが重要ではなく，人々 がさまざまな感じ方をして, 幾通りかの質感をも つことを肯定して詳細を明らかにすることにも力 を注がねばならない。

（2）錯視

心理学の 1 派であるゲシュタルトの研究者に は，形の組み合わせや色の組み合わせによって 種々の視覚上の錯覚 (錯視現象) が起こることを 明らかにしている ${ }^{20)}$ 。実際に, 彼らが指摘している と㧍りにモデルをつくると，確かに透明性のない ものどうしの組み合わせでも透明感を覚える ${ }^{21)}$ 。 このような現象は色彩の場合にはよく起こり，色 の対比現象，同化現象などといわれるものがそれ である。色彩に関するこれらの心理現象について は解明が進んでいるが，透明感のほうについては 研究者も少なく，特に定量的なものは手がついて いない。

(3) 標準光透過票の色調

歯冠用の標準光透過票を試作する時に，色味を 付けないでつくるか, なんらかの歯に似せた色調 でつくるか迷うところである。透明性を目視で観

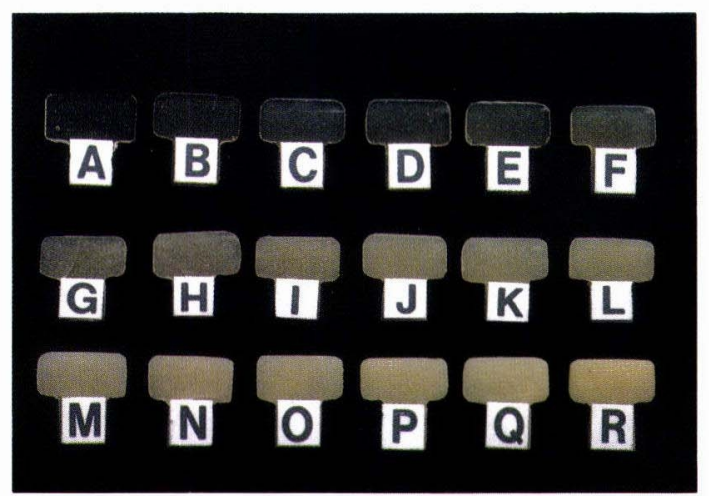

困 10 試作した歯冠用標準光透過票（臨床的呼称は へーズ・ガイド)。表 7 に示した理論值に基づき 許容へーズ差以内に調整した。材料は試作品の ためアクリリックレジン。隣り合う各タブの間 には，視覚的に均等な透明感の差が得られた 
察するということは，対象のものをみるというこ とである。このものをみるということは，そのも のの色をみるということとも同じになる。した がって, 透明感を観察する場合に, 標準光透過票 と対象歯の色も同時に視覚に入る。ところが，天 然歯の色調が一様でないことは臨床家ならば知ら ない人はいないし，実際に学術報告も数多い。そ こで，幅広い天然歯の色調のいずれにすれば測定 しやすいのか，歯冠用標準光透過票と測定対象の 間の色差が透明感にどれほど量的に影響するかは 全く不明である。しかし，指宿 ${ }^{22)} に よ る と ，$ 標準光 透過票の色調が透明感に及ぼす影響は，両者が極 端に離れていなければ定性的，定量的に無視でき るとしている。確かに, 指宿と著者が共同で試作 したもの（図 10）をみる限り，色の 3 属性にばら つきはあっても透明感の等差級数的配列に違和感 はない。したがって，標準光透過票の色調につい ては今後の問題には違いないが, 無彩色でも歯の ような色調がつけられていても問題はないようで ある。しかし，無用に歯との色差が大きな色をつ けるべきではない。

\section{V. 結 論}

1. 透明感という感覚は, Fechner の法則より も Stevens の法則によく適合する。Stevens のべ キ指数 1.74 を得た。したがって, 透明感はプロセ ティック連続体と考えられる。

2. 歯冠用標準光透過票は, ヘーズ值 25.2 91.9\%の範囲で用意し，その間を 18 ステッ プで構成し，低へーズのものは 1 ステップのへー ズ差を大きくとり，高へーズになるにつれて段階 的にへーズ差を小さくすると視覚的に均等へーズ 差になる。すなわち，間隔尺度が得られる。

3. 透明感は，個人差だけでなく同一人の場合 も日間変動する。透明感を 7 段階に分けて言葉で 表現すると，人によって 2 段階ぐらいの開きがあ る。

\section{誎 辞}

稿を終えるにあたり，ご懇篤なるご指導とご校閲を
賜りました長尾正憲教授に染甚の感謝を捧げますと ともに，終始懇切丁寧なるご教授とご指導を賜りまし た指宿真澄非常勤講師（フィフティー・リミテッドカ ンパニー）に心より感謝いたします。また，多大なご 協力を下さいました教室の皆様に厚く御礼申し上げ ます。

\section{文献}

1) Perston, J. D. and Bergen, S. F. : Color Science and Dental Art. St. Louis, 1980, Mosby, 51-71.

2) Lemire, P. A. and Burk, B. : Color in Dentistry. Hartford, 1975, Ney, 50-58.

3) McLean, J. W.: The Science and Art of Dental Ceramics vol.1 The Nature of Dental Ceramics and Their Clinical Use. Chicago, 1979, Quintessence, 122-129.

4) McLean, J. W. : The Science and Art of Dental Ceramics vol.2 Bridge Design and Laboratory Procedures in Dental Ceramics. Chicago, 1980, Quintessence, 21-44.

5) Preston, J. D. : Current status of shade selection and color matching. Quintessence International $16: 47-58,1985$.

6) Baur, A. J. : Die problematik der farbwahl und farbubermittlung. Die Quintessenz der Zahntechnik 12:1323-1332, 1986.

7）指宿真澄：歯冠色のアート. 東京, 1991, 而至歯 科工業 (侏), 16 .

8）加藤愛子：歯冠色の構成に関する色彩学的研究. 補緅誌 $20: 570-584,1977$.

9) Ibusuki, M. : Discrimination threshold for translucent difference of Teeth. 昭歯誌 10 : 62-65, 1990.

10）Guilford, J. P. (秋重義治)：精神測定法. 東京, 1959, 培風館, 126-145.

11）中村和夫：感覚尺度構成。心理学研究 36 ： 202-211，1965.

12）柿崎祐一：現代の心理学 1 知覚判断. 東京, 1974, 培風館, 16-22.

13）三浦 新, 和仁皓明, 吉村 功：工場における官 能検査の進め方. 東京, 1966, 日科技連出版社, 104 .

14）佐藤 信：官能検査入門．東京， 1978 , 日科技連 出版社, 153 .

15) Kubelka, P. und Munk, F. : Ein beitrag zur optik der farbanstriche. Zeitschr. f. techn. Physik 12 : 593-601, 1931.

16）中谷和夫：尺度構成法. 八木 冤監修; 計量心理 学 (講座心理学, 第 2 卷). 東京, 1969 , 東京大学 出版会, 147 .

17）中島義明：実験心理学の基礎. 東京，1992，誠信 
書房, 80-86.

18）須賀長市：耐候光と色彩．東京，1988，スガ試験 機 (侏), 291-316.

19) Ibusuki, M. : The color of gingiva studied by visual color matching Part I . Experimental studies on the discrimination threshold for color difference and effect of training. Bull Tokyo Med Dent Univ 22:249-261, 1975.

20) Kanizsa, G. : Organization in Vision. New
York, 1979, Praeger Publishers, 151-169.

21）指宿真澄，森山 旭：光硬化性練和液を用いた 多色築盛法の標準化とその臨床応用（II）ジーセ ラオービットの色調分析. Quintessence of Dental Technology 19：211-226, 1994.

22）指宿真澄: Personal communication. 1994, 9, 10. 